\title{
Human Perception on the Effects of Dust Storm on the Health of Residents' of Damaturu Metropolis, Yobe State
}

\author{
Jimme M. A. ${ }^{1, *}$, Disa A. L. ${ }^{2}$ and Ngamdu M. B. ${ }^{3}$ \\ ${ }^{1}$ Department of Geography, University of Maiduguri, Borno State, Nigeria \\ ${ }^{2}$ Government Girls Secondary School, Damaturu, Yobe State, Nigeria \\ ${ }^{3}$ Department of Geography, Yobe State University, Damaturu, Yobe State, Nigeria \\ Corresponding Author: *jimmeam@gmail.com
}

https://doi.org/10.36263/nijest.2020.02.0129

\begin{abstract}
Dust storms are among nature's most violent and unpredictable phenomena. High winds lift dirt or sand particles into the air, unleashing a turbulent, suffocating cloud that reduces visibility to almost nothing in a matter of seconds and cause property damage, injuries, and deaths. Damaturu Metropolis has been experiencing dust storm most frequently more especially during the onset of the rainy season. The study examined the human perception on the effects of dust storm on the health of residents' of Damaturu metropolis with the aim of identifying and examining the causes, frequency, effects of dust storm on human health and socio-economic life of resident and their coping strategies. A total of one hundred (100) copies of interview schedules were administered to residents of Damaturu metropolis. The result indicated that desertification and deforestation are the main cause of dust storm and the frequency of its occurrence is more often and it occurs most frequently in the second quarter of the year at the onset of the rainy season. Its duration of occurrence ranges from thirty minutes to an hour, although sometimes it varies. The identified health effects associated with dust storms include asthma, allergic reaction, injury and Road Traffic Accident (R.T.A). The socio-economic and livelihood of the community is equally affected during the dust storm episodes. The coping mechanisms adopted by residents during the dust storm, includes closing doors and windows and using face masks. The study recommended that residents should remain indoors, wear face masks, plant trees and cover crops, among others.
\end{abstract}

Keywords: Dust Storms, Sand Storm, Health, Damaturu

\subsection{Introduction}

Sand and dust storm (SDS) are lower atmosphere events that occur when strong winds pass over dry loose sand or soil. Dust storms are also known as Haboob, (Arabic for strong wind) and are caused by airborne organic and inorganic debris, ranging from large sand particles to small dust particles, lifted from the surface of the land (American Thoracic Society, ATS, 2018). Sand and dust storm (SDS) is also defined as a meteorological hazard, which is related to the process of wind erosion of surface soil and the mineral dust aerosol emission to the atmosphere (World Meteorological Organization, 2019). It is a meteorological phenomenon common in arid and semi-arid regions. Sandstorms usually refer to as desert sandstorms, such as those in the Sahara Desert, or in places where sand is a more prevalent soil type than dirt or rock. Dust storms arise when a gust front or other strong wind blows loose sand and dirt from a dry surface.

The Sahara Desert is a near-uninterrupted band of sand and scrubland that stretches across the northern third of Africa, and almost four-fifths of the country of Algeria. Strong winds, which drive sand and dust storms, are common in the region, making such storms one of the primary natural hazards of the region (MODIS, 2017). In fact, sandstorms include a considerable amount of fine particles obscuring visibility but still different in size, with larger sand particles being blown closer to the surface. According to Rongxing (2018), dust storm is common not only in arid and semiarid regions but in surrounding areas as well. The deserts in northern Africa and the Arabian Peninsula are the main terrestrial sources of the airborne dust. About one-third of earth's land surface is arid or 
semiarid. The lack of vegetation exposes the unprotected surface of the ground to the processes of denudation. As a steady wind begins to blow, fine particles lying on the exposed ground begin to vibrate.

During the dry season, frequent dust storms are one of the main meteorological hazards affecting the population. Outbreaks of meningococcal meningitis, a bacterial infection of the thin tissue layer that surrounds the brain and spinal cord, occur worldwide, yet the highest incidence is found in the "meningitis belt", a part of sub-Saharan Africa extending from Senegal to Ethiopia and including the entire territory of Burkina Faso (Almansa et al., 2017). Airborne dust transport has diverse effects at local, regional and global health scales, due to the presence of high concentrations of airborne mineral dust (e.g. health, energy and transportation) from 48 countries (Wilbert et al., 2018).

The most well-understood health threat from these storms is the dust particles themselves. If small enough, they can slip past a body's natural defenses nose hairs, for example to infiltrate and damage one's respiratory system (Middleton and Kang, 2017). One of the things about dust storms that worry people today is the effects that they can have on their everyday lives. Dust storms can have a devastating effect on agriculture, crops and livestock, commerce, the health and general wellbeing of the people in the affected area, and even on Mother Nature herself. One of the most hazardous effects of a dust storm is the reduction in visibility to less than a quarter of a mile, however in some cases, it can be much less. Urban communities are not immune to the harmful effects of dust storms either. Every day busy transactions can be effected in a negative way when a dust storm hits. One thing that is a concern when a dust storm hits a town or city is power outages and infrastructure damage. The dust particles in the air can lead to a number of respiratory problems, asthma especially. However, dust storms do have some sort of effect in almost every aspect of our daily lives, whether one is a farmer or a business man. The frequent SDSs in Northern Africa, Middle East and Europe, Arabian Peninsula, Central Asia, Northern India, Northern, North-Western China, Southern Mongolia and adjacent Asian countries; and in desert regions of Australia and the USA seriously threaten human health, agriculture, aviation, ground transportation, solar energy industry, air quality, infrastructure and industry, as well as aquatic and terrestrial ecological systems (World Meteorological Organization, 2019). Dust aerosol can carry irritating spores, bacteria, viruses and persistent organic pollutants. It also transports nutrients to the oceans and affects marine biomass production, which affects the changes of greenhouse gases in the marine environment. The Intergovernmental Panel on Climate Change (IPCC, 2018) recognizes that dust aerosol as a major component of atmospheric aerosol as an essential climate variable. More and more, dust particles are considered by atmospheric researchers as an important factor influencing weather through feedback on atmospheric dynamics, clouds and precipitation formation.

In desert areas, dust and sand storms are most commonly caused by either thunderstorm outflows, or by strong pressure gradients which cause an increase in wind velocity over a wide area. Drought and wind contribute to the emergence of dust storms, as do poor farming and grazing practices by exposing the dust and sand to the wind. One poor farming practice which contributes to dust storms is dryland farming. Particularly poor dryland farming techniques are intensive tillage or not having established crops or cover crops when storms strike at particularly vulnerable times prior to revegetation (Emergency Management Plan, (EMP, 2013). In a semi-arid climate, these practices increase susceptibility to dust storms.

Dust storms which easily eject large quantities of dust in the atmosphere leading to the accumulation of heavy metals in the environment are a common experience in most parts of Yobe State, Nigeria. Damaturu being at the fringes of the Sahara desert experiences a lot of dust storms annually. Dust storms are experienced more often during the dry season and at the onset of the rains. The dust storm causes poor visibility and so many other health related discomfort and allergies. So far, there are little or no studies on the effects of dust storms on human health in Damaturu Metropolis. However, previous studies conducted by Waziri and Abdulrahman (2012) and Mohammed and Crump (2013) concentrated on the characterization and elemental compositions of dust particles to quantify the chemicals present in the samples analysed as well as their potential health effects but did not assessed the perception of the residents on the health effects of sand/dust storms in the Damaturu communities, and hence the need to examines the Residents perception on the health effects dust storms. It is 
against this backdrop that this study therefore examined the Residents perception on the effects of dust storms on human health in Damaturu Metropolis of Yobe state.

\subsection{Methodology}

\subsection{Study area}

Damaturu is located at latitude $11^{\circ} 45^{\prime} \mathrm{N}$ and longitude $11^{\circ} 55^{\prime} \mathrm{E}$ (Figure 1). The town has total land area of 2,366 sq kilometres (409,976 hectares) and 456m elevation above sea level. Damaturu is the headquarter of Damaturu Local Government in 1976 and in 1991 it became the Capital of Yobe State, created on 27th of August,1991 out of former Borno State (Wikipedia, 2016). Damaturu is one of the 17 Local Government Areas of Yobe State. The history of Damaturu local government can be trace back to 1810, when the town was founded. The first settlers Damaturu were hunters 'Bukar Sunoma'. He called the place "Daturum" the word is a Kanuri term meaning "Abundant Meat". The climate of Damaturu is a semi-arid one which falls under the Sudan savannah which is most often characterized by short wet season that last for about four mouths and long dry season of about eight months. The area has single peak, which occurs between Augusts and September and mean annual rainfall of $729 \mathrm{~mm}$. The temperature is fairly consistent, and the hottest months are March, April and May fluctuating from season to season. The Temperature of Damaturu ranges between $30^{\circ} \mathrm{C}$ and $42^{\circ} \mathrm{C}$, and the rainfall ranges between $400 \mathrm{~mm}$ and $800 \mathrm{~mm}$ and annual mean of $750 \mathrm{~mm}$. Aside from the northeast trade wind that is associated with dry season, there is the southwest maritime air masses that is associated with the wet season (Babalola and Busu, 2011). Vegetation cover in Damaturu is directly related to environmental factors such as soil, rainfall and human intervention. Damaturu which was founded in 1813 is pluralistic in ethnic composition. The State capital is composed of ethnic groups with rich and diverse historical and cultural heritages such as the Fulani and Kanuri as the dominant ethnic groups. Others are the Hausas, Kare-Kare, Bolewa, Bade, Ngizim, Ngamo, Babur and Maga, Karai-Karai, Bade and minority tribes of other states like the Igbos, Yorubas and Tivs are also found as traders and public servants. The population of Damaturu was put at 88,014 persons by the National Population Commission based on the 2006-population census, with a growth rate of $0.032 \%$. However, this figure has risen to 119,842 as projected by (NPC, 2019) and due to the influx and eventual settling of IDPs in the Metropolis. With the state creation in 1991, a large number of smallscale industries, rubber processes industry and a modern a bateau were established in the town. The town is richly endowed with mineral and agricultural resources like gypsum, kaolin, limestone, diatomite, granites, silica, potassium and soda ash. In the agro-allied sector, the following agricultural products are grown in large quantities namely millet, rice, maize, guinea corn, beans, cotton, groundnut, gum Arabic and livestock or rearing of animals which support the life of the people.

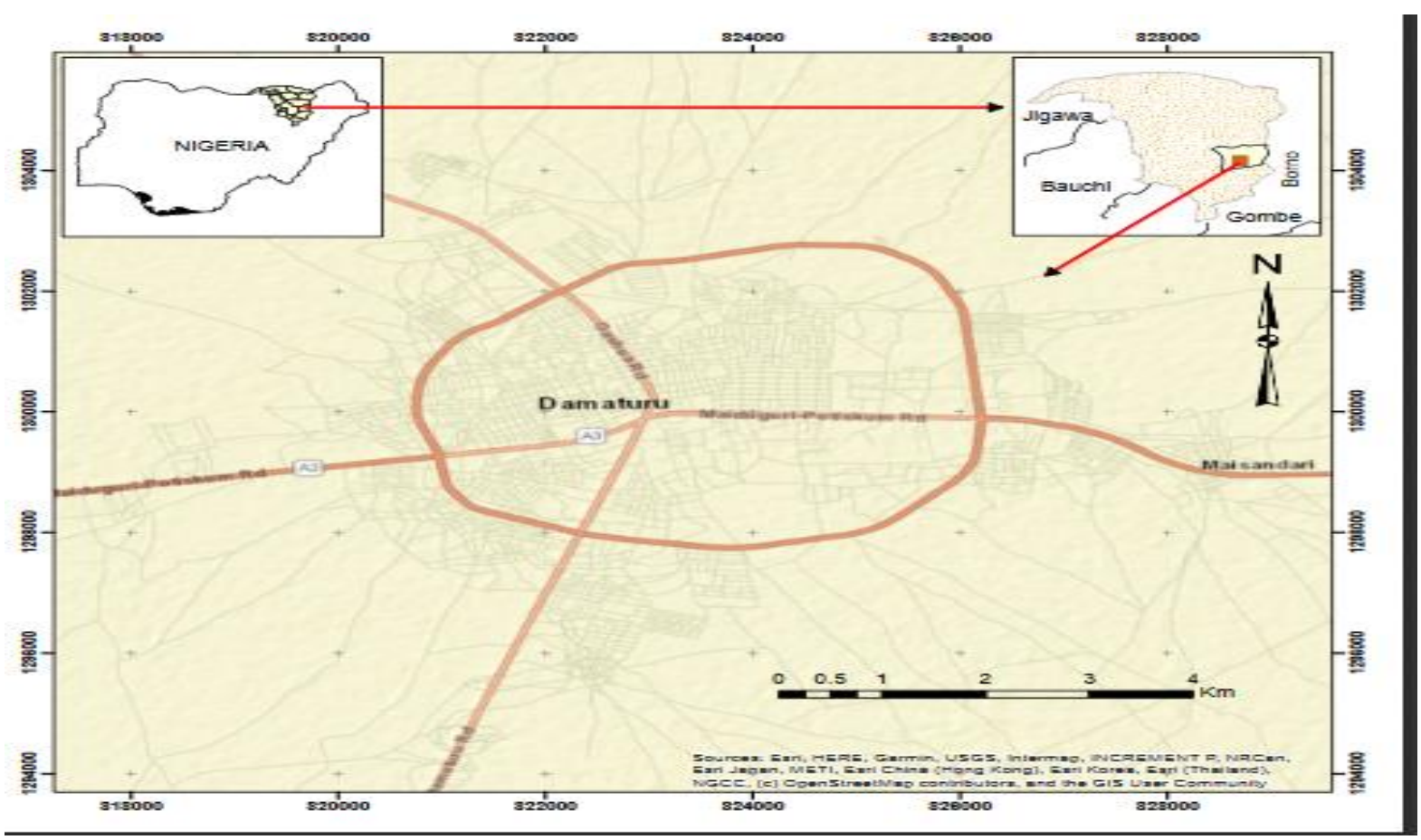

Figure 1: Yobe State, Damaturu Metropolis (Study Area) 


\subsection{Methods}

The study was designed to investigate the effects of dust Storm on the human health of residents of Damaturu metropolis. The nature of data generated includes information on the causes of dust storm, intensity of dust storm, effects of dust storm on human health and the effects of dust storm on the socio-economic livelihood of the people in the metropolis. The primary data includes questionnaires, physical observation, Key Informants Interview (KII) and In-Depth Interviews (IDI). The secondary data on the other hand includes in and out patient hospital records, journals, final year essays, seminar papers and the internet. The metropolis consists of eleven (11) wards namely: Damaturu Central, Bindigari/Pawari, Nayi-Nawa, Gwange, Kalallawa-Gabai, Sasawa, Kukareta, Damakasu, Gambir, Maisandari/waziri Ibrahim and Murfakalam. A total of 100 respondents (10\%) were purposively and randomly selected using simple random sampling from the population range of the peak years of outpatient record. Samples in qualitative research tend to be small in other to support the depth of case oriented analysis which is fundamental to this study. As a result, purposive sampling as opposed to probability sampling was employed to achieve the desired objective. The generated data was analysed using both the qualitative and quantitative method of analysis. The questionnaires were coded and analysed using simple percentage, frequencies and cross tabulation. The qualitative data was equally transcribed and interpreted to a meaningful result.

\subsection{Results and Discussion}

The results of the socioeconomic characteristics of respondents in Table 1 indicated that over half (52 percent) of the respondents are males, while 48 percent are females. The group shows that 50 percent are above the age of 40 years indicating a much matured respondents with over 40 percent of them well educated to a tertiary level, while 30 percent attended secondary education, an evidence of high level of literacy to responds to the questionnaires adequately. On the other hand, majority (30 percent) are either civil servants or retirees.

Table 1: Socioeconomic characteristics of respondents

\begin{tabular}{|l|l|l|}
\hline & No. of respondents & Percentage (\%) \\
\hline Sex of respondents & & \\
\hline Male & 52 & 52 \\
\hline Female & 48 & 48 \\
\hline Age of respondents & & \\
\hline $18-29$ & 10 & 10 \\
\hline $29-39$ & 40 & 40 \\
\hline 40 -above & 50 & 50 \\
\hline Qualification of respondents & & \\
\hline Tertiary & 40 & 40 \\
\hline Secondary & 30 & 30 \\
\hline Qur'anic & 12 & 12 \\
\hline Primary & 09 & 09 \\
\hline Others & 09 & 09 \\
\hline Occupation of respondents & & \\
\hline Civil servant & 30 & 30 \\
\hline Trader & 10 & 10 \\
\hline Retiree & 30 & 30 \\
\hline Farmer & 10 & 10 \\
\hline Others & 20 & 20 \\
\hline Total & 100 & 100 \\
\hline
\end{tabular}

The perception of respondents on causes of dust storm was sought. The findings indicate that over 65 percent of respondent described dust storms as strong and heavy windstorms experienced annually, while 10 percent of the respondents perceived it as a natural hazard due to its associated environmental effects. The results in Table 2 indicate that 49 percent of respondents reported that desertification is the main cause of dust storm in the study area, 20\% indicate that drought is the cause and 3\% attributes it to nature caused by Act of Nature. 
Table 2: Causes of dust storm

\begin{tabular}{|l|l|l|}
\hline Causes of dust storm & Frequency & Percentage (\%) \\
\hline Deforestation & 30 & 30 \\
\hline Overgrazing & 05 & 5 \\
\hline Bush burning & 03 & 3 \\
\hline Drought & 20 & 20 \\
\hline Desertification & 49 & 49 \\
\hline Act of Nature & 03 & 3 \\
\hline Total & 100 & 100 \\
\hline
\end{tabular}

The findings in Table 3 indicated that $50 \%$ of respondents are of the opinion that Dust storm occur "often" in the study area, where as $40 \%$ reported that it occur most "often". The findings equally shows that $80 \%$ of respondents are of the opinion that dust storm are more frequent in the second quarter of the year while $10 \%$ think it is more frequent in the $3^{\text {rd }}$ quarter of the year. However, physical observations of dust storms shows that they are more frequent at the end of the first quarter and at the beginning of the second quarter, during the onset of the rain in the study area. This finding disagrees with the NOAA's findings (2019), that dust storm happens frequently late spring through early autumn and every three to five days. This dust storm is different from the harmattan haze that occurs in December and runs till February in the northeast part of Nigeria.

Table 3: Frequency of occurrences of dust storm

\begin{tabular}{|l|l|l|}
\hline Frequency & No. of respondents & Percentage (\%) \\
\hline Often & 50 & 50 \\
\hline Most often & 40 & 40 \\
\hline Not often & 09 & 9 \\
\hline Not at all & 01 & 1 \\
\hline Total & 100 & 100 \\
\hline
\end{tabular}

\subsection{Duration of dust storms during occurrence}

The findings indicates that 40 percent of respondents believes that dust storm last for 2 hours, while 20 percentage of respondents thinks it last for 3 hours, another $20 \%$ indicate that time varies when it occur. Although, some studies indicates that in recent years, the onset of the rainy season (June to October) in most parts of the north-eastern semi-arid region of Nigeria is characterized by the heavy dust storms, and accompanied by reduced visibility for 3-5 minutes, physical observations during storms shows that it last much more than that to 15- 30 minutes or there about and in some cases mostly followed by torrential rains with thunderstorms, leaving behind heavy dust deposits, which settle down on every available surface and most often in areas with less vegetation cover and relatively dry zones.

\subsection{Effects of dust storms}

It was confirmed by studies conducted by ATC (2018), Sand and Dust storms can cause respiratory problems for people who are exposed, particularly those who have lung disease. The winds caused blowing sand and dust to fill the air, severely limiting visibility and bringing traffic to a halt (Plate 14). It is associated with increases in emergency department visits, hospital admissions, as well as increases in asthma and respiratory diseases exacerbations (flare-ups). In the semiarid and arid regions with limited vegetation, this scenario seems to be worst. Outdoor environmental dust has been linked to numerous health problems. Fine dust particles can carry a range of other harmful things including bacteria, virus, fungi, pollutants and allergies. Dust storm exposure may cause or worsen: irritation of the eyes, nose and throat, coughing and wheezing, lower respiratory tract infections (viral, bacterial and fungal including coccidioidomycosis), obstructive airway diseases (asthma, bronchitis, COPD), lung fibrosis (sand and dust storm associated silicosis), interstitial lung disease and cardiovascular diseases. The findings presented in Table 4 indicated a wide range of health conditions related with dust storms. 
Table 4: Effects of dust storm on human health

\begin{tabular}{|l|l|l|}
\hline Effects & No. of Respondents & Percentage (\%) \\
\hline Asthma & 28 & 28 \\
\hline Respiratory Tract Infection & 20 & 20 \\
\hline Road Traffic Accident & 18 & 18 \\
\hline Body Injury & 10 & 10 \\
\hline Allergic Reaction & 24 & 24 \\
\hline Total & 100 & 100 \\
\hline
\end{tabular}

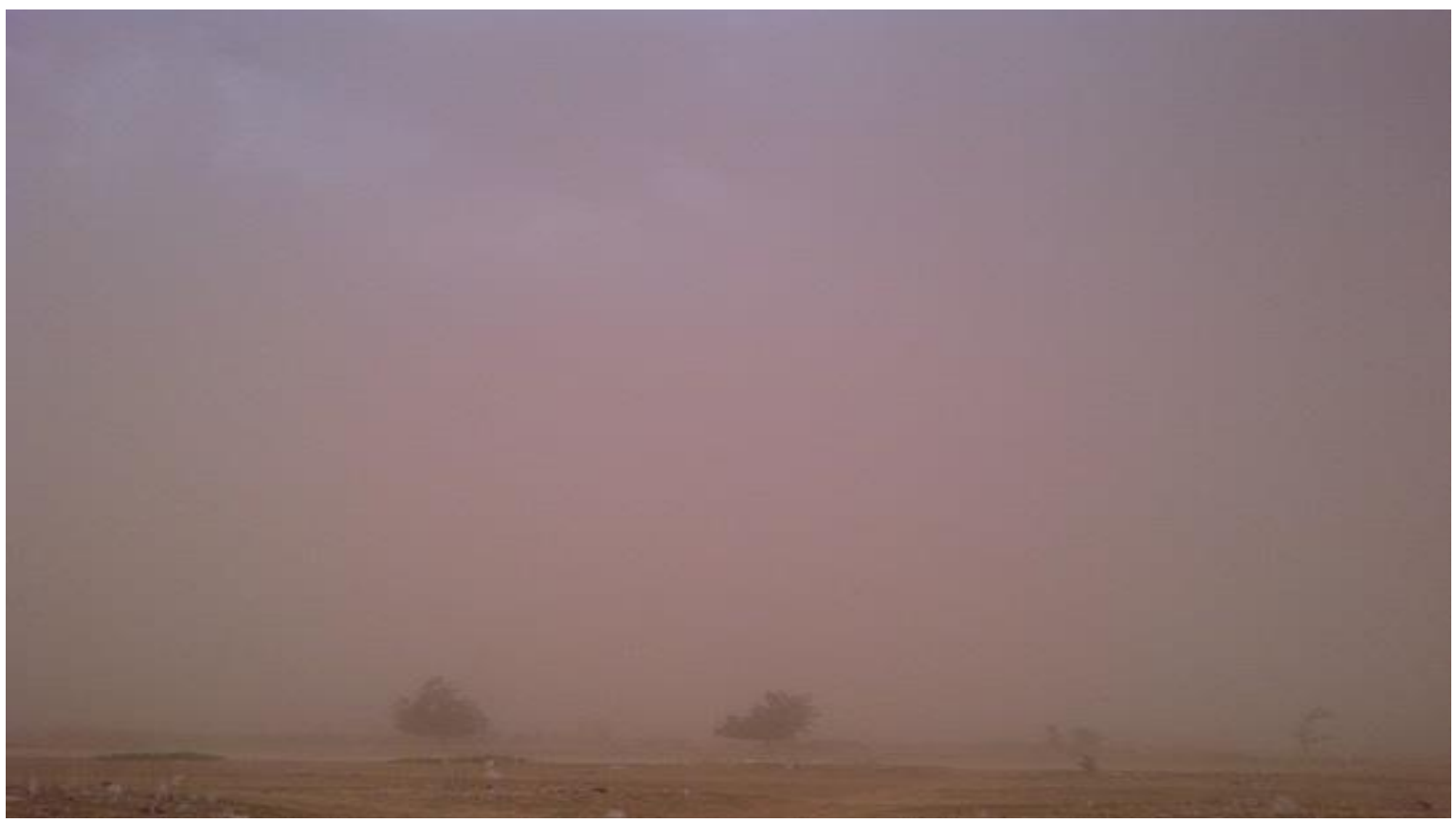

Plate 1: The onset of dust storm at Bindigari Ward of Damaturu Metropolis

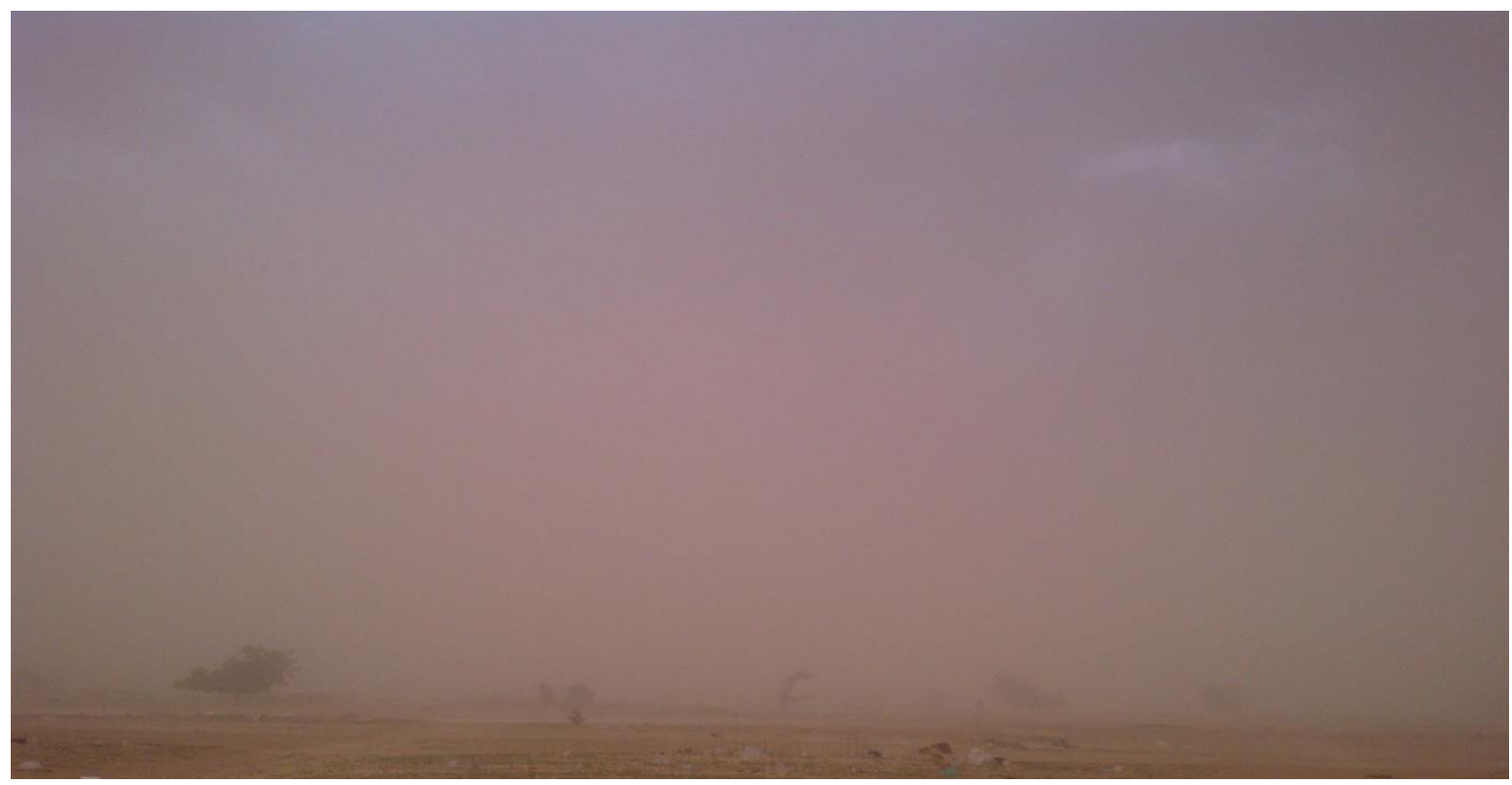

Plate 2: Dust storm occurring at Malari Ward of Damaturu Metropolis 




Plate 3: Dust storm occurring at Sasawa Ward of Damaturu Metropolis



Plate 4: Dust storm setting in at the outskirt of Damaturu Metropolis

The results in Table 4 indicates that 28 percent of respondents reported that dust storm causes asthma, 24 percent believes that it causes allergic reactions while 20 percentage of the respondents indicated that it causes respiratory tract infection. Whatever the responses are the study confirmed that the storm has enormous effects on both the health and the livelihood of the residents. As also observed by Mohammed and Crump (2013), in Damaturu and the surrounding communities local people attribute various types of ailments ranging from eye inflammatory diseases, gastro-intestinal disorders and respiratory tract infections to the dusty weather conditions observed in the area. During the dust events people spend much of their time indoors. In addition, the dust that settles indoors lingers within the home and therefore exposure continues even after adjust event.

Table 5 shows result from hospital records, which indicate that allergic reaction is on the increase from 2012 to 2019. Number of asthma cases has also increase. This may be due to frequent 
occurrence of dust storm and the large influx of internally displaced persons into Damaturu metropolis as a result of the insurgency in the North East. The dust storm has been confirmed to have both short and long term effects. The short-term effects of exposure to desert dust include immediate increased symptoms and worsening of the lung function in individuals with asthma, increased mortality and morbidity from long-transported dust from both Saharan and Asian dust storms suggesting that long-transported dust storm particles adversely affects the circulatory system. Prolonged and unprotected exposure of the respiratory system in a dust storm can also cause silicosis, which, if left untreated, will lead to asphyxiation; silicosis is an incurable condition that may also lead to lung cancer. There is also the danger of keratoconjunctivitis sicca ("dry eyes") which, in severe cases without immediate and proper treatment, can lead to blindness. This has been confirmed by studies conducted by ATC, 2018, Almansa et al., 2017, Rongxing, 2018; Wilbert et al., 2018; WMO, 2019.

Table 5: Table showing the record of in-patient

\begin{tabular}{|c|c|c|c|c|c|c|c|c|c|}
\hline \multirow{2}{*}{ Diseases } & \multicolumn{8}{|c|}{ Year } & \multirow{2}{*}{ Total } \\
\hline & 2012 & 2013 & 2014 & 2015 & 2016 & 2017 & 2018 & 2019 & \\
\hline Allergic reaction & 111 & 150 & 209 & 256 & 287 & 301 & 325 & 346 & 1985 \\
\hline Asthma & 90 & 103 & 108 & 119 & 128 & 134 & 145 & 157 & 984 \\
\hline Road Traffic Accident (R.T.A) & 50 & 48 & 50 & 54 & 59 & 63 & 66 & 71 & 461 \\
\hline Total & 251 & 301 & 367 & 429 & 474 & 498 & 536 & 574 & 3430 \\
\hline
\end{tabular}

Source: Medical Record; State Specialist Hospital, Damaturu, 2019

Results from the hospital records presented in Table 6 shows that within the last eight years, there was an increase in allergic reactions and Asthma attack among patients in all the years, except for road traffic accident which was attributed to awareness creation and the effect of insurgency which makes motorist to avoid the highway during dust storm. The results equally indicated that allergic reaction is on the increase from 2012 to 2019. The number of asthma cases has also increased. This may be due to frequent occurrence of dust storm.

Table 6: Table showing the record of out-patient

\begin{tabular}{|l|l|l|l|l|l|l|l|l|l|}
\hline \multirow{2}{*}{ Diseases } & \multicolumn{7}{|c|}{ Year } & \multirow{2}{*}{ Total } \\
\cline { 2 - 11 } & 2012 & 2013 & 2014 & 2015 & 2016 & 2017 & 2018 & 2019 & \\
\hline Allergic Reaction & 375 & 465 & 470 & 474 & 480 & 532 & 568 & 616 & 3980 \\
\hline Asthma & 489 & 398 & 420 & 441 & 474 & 499 & 553 & 591 & 3865 \\
\hline Road Traffic Accident & 292 & 281 & 216 & 201 & 193 & 172 & 169 & 161 & 1685 \\
\hline Total & 1156 & 1144 & 1106 & 1116 & 1147 & 1203 & 1290 & 1368 & 9530 \\
\hline
\end{tabular}

Dust storms cause soil loss from the dry lands, and worse, they preferentially remove organic matter and the nutrient-rich lightest particles, thereby reducing agricultural productivity. Also the abrasive effect of the storm damages young crop plants. Dust storms also reduced visibility affecting aircraft and road transportation. In addition dust storms also create problems due to complications of breathing in dust (Goudie, 2014; Earth Snapshot, 2013). The result in Table 7 indicate that 50\% of respondents confirmed that dust storm cause destruction of infrastructure, $28 \%$ indicates that it destroys agricultural crops and generates erosion through washing up the top soil and destruction of plants. While 23\% responded it disrupt religious and social activities, like congregation prayers, funeral prayers, preaching, wedding and naming ceremonies. Dust storm also reduces visibility to less than a quarter of a mile, however, in some cases can be much less than (Earth Snapshot, 2013) these by resulting in road traffic accident (R.T.A) (Plate 5 and 6).

Table 7: Effects of Dust Storm on Socio-economic and livelihood of the people

\begin{tabular}{|l|l|l|}
\hline Effects & No. of respondents & Percentage (\%) \\
\hline Destruction of infrastructure & 50 & 50 \\
\hline Destruction of agricultural crops & 28 & 28 \\
\hline Disruption social and religious activities & 23 & 23 \\
\hline Total & 100 & 100 \\
\hline
\end{tabular}




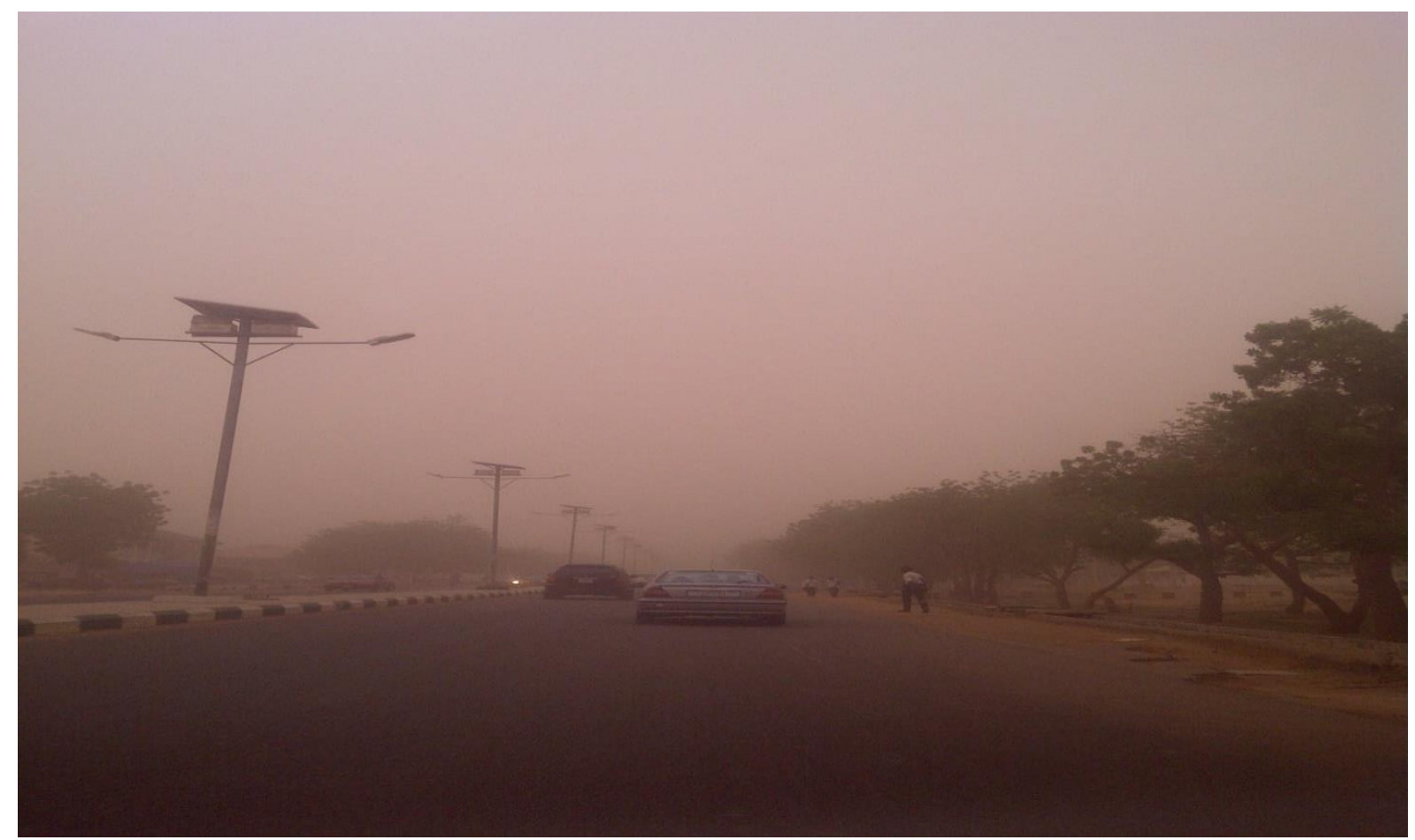

Plate 5: Onset of a dust storm at Central Area of Damaturu Metropolis

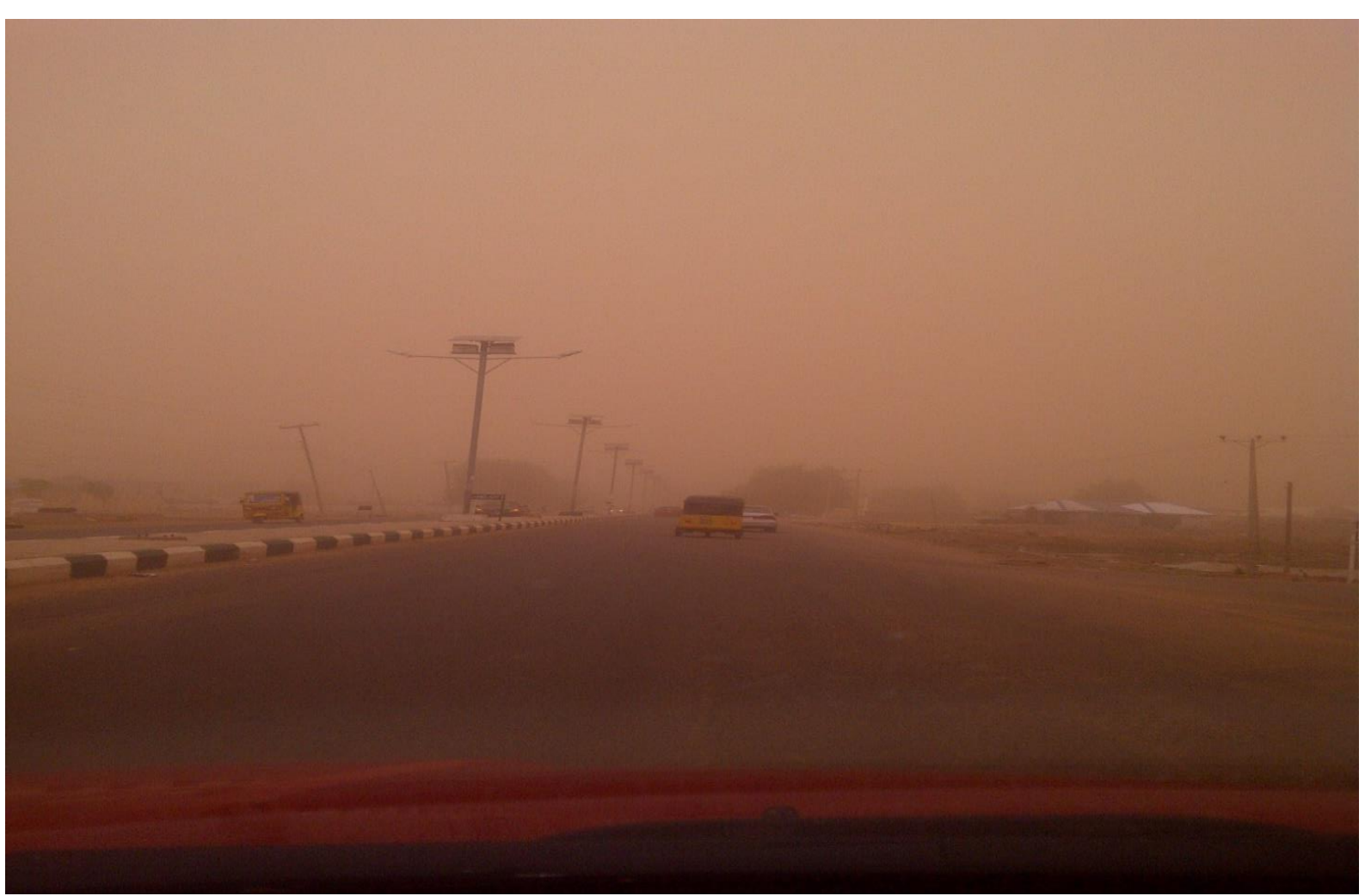

Plate 6: Dust storm occurring at the Central Area of Damaturu Metropolis

The finding in Table 8 shows that $70 \%$ of the respondents stated that strategies adopted during dust storm include closing of doors and windows, while $20 \%$ of respondent make use of face mask and $10 \%$ responded that they don't adopt any coping strategy or mechanisms at all, against allergic reactions and other dust related ailments such as asthma instead they do nothing at all rather they allow the storm to comes and pass. 
Table 8: Coping strategies adopted during a dust storm in the community

\begin{tabular}{|l|l|l|}
\hline Coping strategies & No. of respondents & Percentage (\%) \\
\hline Closing door and windows & 70 & 70 \\
\hline Use of face mask & 20 & 20 \\
\hline Nothing at all & 10 & 10 \\
\hline Total & 100 & 100 \\
\hline
\end{tabular}

The findings in Table 9 show that $50 \%$ respondents suggest that afforestation is the best way of curtailing the frequency of dust storm in the study area, while planting cover crops and public enlightenment was suggested by $25 \%$ respectively as a way of curtailing or cubing dust storm.

Table 9: Strategies for curtailing the frequency of dust storm

\begin{tabular}{|l|l|l|}
\hline Strategies & No. of respondents & Percentage (\%) \\
\hline Planting cover crops & 25 & 25 \\
\hline Afforestation & 50 & 50 \\
\hline Public enlightenment & 25 & 25 \\
\hline Others & - & - \\
\hline Total & 100 & 100 \\
\hline
\end{tabular}

\subsection{Conclusions}

Dust and sand storms are among nature's most violent and unpredictable phenomena. High winds lift dirt or sand particles into the air, unleashing a turbulent, suffocating cloud that can reduce visibility to almost nothing in a matter of seconds and cause property damage, injuries, and deaths. Dust storms has a strong association between dust events and a range of human health issues, including respiratory problems, cardiovascular complaints, meningococcal meningitis, conjunctivitis, skin irritation, and deaths and injuries associated with transport accidents and infrastructural damage. Although, the human effects of dust storms are enormous, residents are taking the disaster with less caution. There is a strong need for sensitization on the health and socioeconomic implications of dust storms. Based on the findings the study recommended that: Residents should moisten a mask a little and put it over their nose and mouth. The eyes should be protected during a dust storm using airtight goggles or eyeglasses to offer minimal protection from blowing dust or sand. Residents should wrap a piece of cloth tightly around their heads to protect the eyes and ears and look for shelter to shield themselves by staying indoors against flying objects avoid moving around. Due to dropping visibility all vehicles should pull over, stop and stay off the roads to avoid accidents and being attacked by Boko Haram Insurgents during a dust storm.

\section{References}

Almansa, A. F., et al. (2017). A new zenith-looking narrow-band radiometer-based system (ZEN) for dust aerosol optical depth monitoring. Atmospheric Measurement Techniques, 10(2), pp. 565-579.

American Thoracic Society (2018). Sand and Dust Storms: Acute Exposure and Threats to Respiratory Health, Patient Education/ Rapid Response Series. ATS Patient Education Series @2018 America Thoracic Society. Available at: www.thoracic.org/patients/patients-resources/resources/sandand -dust storms.pdf. Accessed December, 2019.

Babalola, A. and Busu, I. (2011). Selection of Landfill Sites for Solid Waste Treatment in Damaturu Town-Using GIS Techniques. Journal of Environmental Protection, 2, pp. 1-10.

Earth Snapshot (2013). Dust Between Tigris and Euphrates Rivers, Iraq. Earth Snapshot. March 3, 2013. Retrieved 2013-11-20.

EMP (2013). Dust Storms Chapter (PDF). Emergency Management Plan. State of Oregon. Archived from the original (PDF)on 2013-10-21. Available at:

http://csc.uoregon.edu/opdr/sites/csc.uoregon.edu.opdr/files/docs/ORNHMP/OR-SNHMPduststorms_chapter.pdf

Goudie, A. S. (2014). Desert dust and human health disorders. Environment International, 63, pp. 101-113. doi:10.1016/j.envint.2013.10.011. 
IPCC (2019). Explainer: Desertification and the Role of Climate Change. Intergovernmental Panel on Climate Change Report, Carbon Brief 08/06/2019.

MODIS (Moderate Resolution Imaging Spectroradiometer), Dust Storm in the Sahara Desert, NASA. Available at: https://modis.gsfc.nasa.gov/gallery/individual.php?db_date=2017-05-22

Mohammed, F. S. and Crump, D. (2013). Characterization of Indoor/Outdoor Settled Dust and Air Pollutants in Damaturu, Nigeria. International Journal of Engineering and Technology (IACSIT), 5(1), pp. 104-108.

Middleton, N. and Kang, U. (2017). Sand and Dust Storms: Impact Mitigation. Sustainability, 9(6), 1053. www.mdpi.com/journal/sustainability

NPC (2019). National Population Commission, Damaturu Projected Population.

NOAA (2019). Satellite Tracking Dust and Sand Being Blown from Sahara Desert, National Oceanic and Atmospheric Administration, NOAA National Environmental Satellite, Data and Information Service (NEDIS), Satellite and Information Service, U.S. Department of Commerce.

Rongxing, G. (2018). Cross-Border Environmental Pollution and Management (Third Edition), Elsevier, pp. 233-268.

Waziri, M. and Abdulrahman, A. A. (2012). Household dust and air quality in Damaturu, Nigeria. Bulletin of Pure \& Applied Sciences- Chemistry, 31(2), pp. 59-68.

Wilbert, S., et al. (2018). Sunshape measurements with conventional rotating shadowband irradiometers. AIP Conference Proceedings, 2033(1): 190016.

World Meteorological Organization (2019). Airborne Dust Bulletin, Sand and Dust Storm - Warning Advisory and Assessment System, No. 3, May 2019.

Cite this article as:

Jimme M. A., Disa A. L. and Ngamdu M. B., 2020. Human Perception on the Effects of Dust Storm on the Health of Residents' of Damaturu Metropolis, Yobe State. Nigerian Journal of Environmental Sciences and Technology, 4(2), pp. 421-431. https://doi.org/10.36263/nijest.2020.02.0129 